\title{
Amalgam Versus Resin Composite for the Restoration of Posterior Teeth: Disparities between Public Clinical Practice and Dental Education in Southern Brazil
}

Amálgama Versus Resina Composta para Restaurações de Dentes Posteriores: Diferenças entre a Prática Clínica no Serviço Público e o Ensino em Faculdades de Odontologia no Sul do Brasil

\section{Clarissa Fatturi Parolo ${ }^{1}$, Aline Macarevich ${ }^{2}$, Juliana Jobim Jardim ${ }^{1}$, Marisa Maltz ${ }^{3}$}

\section{Resumo}

Objetivo: Comparar o material restaurador indicado no tratamento de dentes posteriores de acordo com o ensino e realização dos tratamentos em duas Faculdades de Odontologia (UFRGS e ULBRA) e em 8 unidades básicas de saúde (UBS) do Sistema de Saúde Pública em Porto Alegre, Brasil.

Materiais e Métodos: Os dados referentes ao ensino de procedimentos restauradores utilizando amálgama (AM) ou resina composta $(\mathrm{RC})$ foram obtidos através da análise de prontuários de pacientes a questionários aplicados aos estudantes de Odontologia do último ano. Informações sobre os procedimentos restauradores nas UBS foram obtidas através de prontuários de pacientes e de questionários aplicados aos dentistas. $\mathrm{O}$ tipo de material restaurador utilizado nas Faculdade de Odontologia e nas UBS forma comparados através de teste Qui-quadrado.

Resultados: Na UFRGS, 327 restaurações foram realizadas, sendo $78,28 \%$ RC e 21,72\% AM; na ULBRA, 366 restaurações foram efetuadas, sendo $92,63 \%$ RC e $7,37 \%$ AM. Nas UBS, 1664 restaurações foram realizadas, sendo $35,93 \% \mathrm{RC}$ e $64,07 \% \mathrm{AM}$. Uma maior proporção de restaurações de AM foram realizadas no Serviço Público de Saúde em comparação às Faculdades de Odontologia, nas quais restaurações com $R C$ foram mais prevalentes $(p=0.000)$. Conclusões: A mudança de $\mathrm{AM}$ para $\mathrm{RC}$ na escolha do material restaurador para dentes posteriores em Faculdades de Odontologia não foi seguida pelo Sistema Público de Saúde, onde o AM ainda é largamente utilizado.

Palavras-chave: Amálgama dentário, Resina composta, Restauração dentária permanente, Educação em Odontologia, Saúde Pública, Competência Clínica.

\section{Abstract}

Aim: To compare the restorative material used in the treatment of posterior teeth taught and performed in two Dental Schools (UFRGS and ULBRA) and in 8 basic health units (BHU) from the Public Health System in Porto Alegre, Brazil.

Materials and methods: Data referring the teaching of restorative procedures using amalgam (AM) or resin (R) were obtained through the analysis of patient's files and questionnaires applied to final year dental students. Information regarding restorative procedures at $\mathrm{BHU}$ was obtained through patient's records and a questionnaire applied to the dentists. The type of restorative material used in both BHU and Dental Schools were compared by chi-square test.

Results: At UFRGS, 327 restorations were performed, $78.28 \% \mathrm{R}$ and $21.72 \% \mathrm{AM}$, and at ULBRA 366 restorations, $92.63 \% \mathrm{R}$ and $7.37 \%$ AM. At $\mathrm{BHU}, 1664$ restorations were performed $(35.93 \% \mathrm{R}$ and $64.07 \%$ AM). A major proportion of AM restorations was performed in the Public Health Service in comparison to both Dental Schools, in which resin restorations prevailed $(p=0.000)$.
${ }^{1}$ Associate Professor, Department of Social and Preventive Dentistry, Federal University of Rio Grande do Sul, Porto Alegre, RS, Brazil.

${ }^{2}$ Dentist, Public Health System from Estrela, RS, Brazil.

${ }^{3}$ Professor, Department of Social and Preventive Dentistry, Federal University of Rio Grande do Sul, Porto Alegre, RS, Brazil.

Correspondência: Prof. Marisa Maltz

Endereço: Faculdade de Odontologia - UFRGS

Departamento de odontologia Preventiva e Social

Ramiro Barcelos, 2492, Bom Fim - CEP 90035-003, Porto Alegre - Rio Grande do Sul, Brazil

Fone: (51) 33085247

E-mail: marisa.maltz@gmail.com

Data de Submissão: 13/04/2012

Data de Aceite: 25/06/2012

Conclusion: The change from $\mathrm{AM}$ to $\mathrm{R}$ in the dental material choice for posterior teeth at Dental Schools was not followed by the Public Health System, where the AM is still widely used in posterior teeth.

Keywords: Dental Amalgam, Composite Resins, Dental Education, Public Health Practice, Clinical competence, Dental Restoration.

\section{Introduction}

Despite the aesthetic appeal of modern society, which leads to an increased demand for resin fillings even in posterior teeth, amalgam restorations are still worldwide used (CHRISTENSEN, 1998; MCCOMB, 2005; BERNARDO et al., 2007; MITCHELL; KOIKE; OKABE, 2007). This widespread use for the restoration of posterior teeth is due to straightforward handling procedures, well-tested material properties (CHRISTENSEN, 1998), low price, and well documented clinical success (VAN NIEUWENHUYSEN et al., 2003; BERNARDO et al., 2007). One of the major disadvantages of amalgam fillings is the need of macro-mechanical retention resulting in a larger tooth waste in comparison to adhesive restorative dental materials (DE MOOR; DELME, 2008). In the minimal intervention dentistry concept, the consciousness that preserving sound tooth is more important than making a long-lasting restoration has grown (WILSON, 2004; ROETERS; OPDAM; LOOMANS, 2004). In addition, for environmental reasons and biocompatibility issues, government agencies and patients are demanding for alternatives to amalgam (BURKE, 2004; MCCOMB, 2005; BERNARDO et al., 2007).

The use of resin for restorations of posterior permanent teeth has increased significantly (GILMOUR; EVANS; ADDY, 2007), although it is more technique-sensitive to place (CHRISTENSEN, 1998; WILSON, 2004) and costly (MJOR; WILSON, 1998; TOBI et al., 1999). The adhesive technique from resin restorations assures a reduced tissue removal in comparison to amalgam (ROETERS; OPDAM; LOOMANS, 2004; DE MOOR; DELME, 2008). Tooth 
preparation for resin fillings is restricted to the size of the caries lesion. The strengthening effect on the remaining tooth is also a desirable characteristic of the resin composite (ROETERS; OPDAM; LOOMANS, 2004). However, long-term evaluation of resin restorations in permanent teeth has shown a lower mean survival time in comparison to amalgam restorations (VAN NIEUWENHUYSEN et al., 2003; BERNARDO et al., 2007; MITCHELL; KOIKE; OKABE, 2007). Although satisfactory results have been achieved with current composite material in clinical investigation (PALANIAPPAN et al., 2009), randomized controlled trials do not support the equivalent clinical performances of resin and amalgam restorations (KOVARIK, 2009).

Some Dental Schools discontinued the teaching of the use of amalgam (ROETERS; OPDAM; LOOMANS, 2004), while others had little acceptance to introduce students to the use of tooth-colored materials in posterior teeth (WILSON, 2004). The tension between the teaching of dental amalgam and resin for the restoration of posterior teeth is an example of the dilemma in curricular reform in Dental Schools (BURKE, 2004). In Brazil, the use of the rubber dam is required in most of the restorative procedures at the Dental Schools. General practice dentists, on the other hand, intend to use cotton roll isolation in the Brazilian public health system practice. The distance between the academic practice and the reality of every day clinic is often pointed out as a fault of dental schools teaching.

The aim of this study was to evaluate the restorative material used in the treatment of posterior teeth taught and performed in two Dental Schools (UFRGS and ULBRA) and in the basic health units $(\mathrm{BHU})$ from the Public Health System in Porto Alegre, Brazil.

\section{Materials and Methods}

The restorative treatment taught and performed on two Dental Schools of the metropolitan region of Porto Alegre, RS, Brazil (Federal University of Rio Grande do Sul - UFRGS, and Lutheran University of Brazil -ULBRA/Canoas) was evaluated and compared to the restorative treatment performed in 8 basic health units (BHU) from the Public Health Service (PHS) from this city. Information regarding treatment procedures was also evaluated.

In Dental Schools, records of patients under treatment in all clinics during the 2 nd semester of 2004 were analyzed. Fillings placed by the students on posterior teeth (molars and pre-molars) during this period were included in the study. Data referring the teaching of restorative procedures, type of material used and number of fillings performed were obtained through the analysis of questionnaires applied to the senior students of the undergraduate courses (UFRGS $=35, \mathrm{ULBRA}=40$ ).

Information regarding restorative procedures of the $\mathrm{BHU}$ was obtained through a questionnaire applied to the dentists. The PHS in Porto Alegre is divided in eight districts, each one comprising several dental units. One dental unit per district was selected by lot to participate in the study. The units included in the study were: Ipanema, Passo das Pedras, Bananeiras, Santa Cecília, Restinga, Vila dos Comerciários, Safira Nova, Navegantes. All the dentists from each dental unit included answered the questions $(n=19)$. The clinical files of all patients treated in the PHS during the 2nd semester of 2004 were analyzed regarding restorative procedures performed in posterior teeth.

Descriptive statistics was used to analyze the data obtained from the questionnaires (Public Health Service and Universities). The type of restorative material used in both Public Health Service and Dental Schools were compared by chi-square test analysis at a significance level of $5 \%$. The data were analyzed using the Statistical Package for Social Science (SPSS) version 13.0.

\section{Results}

The undergraduate students from the two Dental Schools (UFRGS and ULBRA) executed 693 direct fillings in posterior teeth from July to December of 2004. At the BHU, 986 patients received 1664 direct fillings in posterior teeth at the same period. A higher number of amalgam fillings was placed in posterior teeth at the $\mathrm{BHU}$ in comparison to Dental Schools, in which resin restorations prevailed $(\mathrm{p}=0.000)($ Table 1$)$.

Table 1: Number and percentage of resin and amalgam fillings executed in premolars (PM) and molars (M) at the Basic Health Unit (BHU) and at Dental Schools (DS) from July to December 2004.

\begin{tabular}{lcccccc} 
& Resin & \multicolumn{5}{c}{ Amalgam } \\
\cline { 2 - 7 } Local & PM & $\mathrm{M}$ & Total & PM & $\mathrm{M}$ & Total \\
\hline DS & 257 & 338 & $595^{\mathrm{a}}$ & 28 & 70 & $98^{\mathrm{b}}$ \\
& $(37.09 \%)$ & $(48.77 \%)$ & $(85.86 \%)$ & $(4.04 \%)$ & $(10.10 \%)$ & $(14.14 \%)$ \\
\hline BHU & 259 & 339 & $598^{\mathrm{a}}$ & 170 & 896 & $1066^{\mathrm{c}}$ \\
& $(15.56 \%)$ & $(20.37 \%)$ & $(35.93 \%)$ & $(10.22 \%)$ & $(53.85 \%)$ & $(64.07 \%)$ \\
\hline
\end{tabular}

$\mathrm{P}=0.000$ (chi-square test); numbers followed by distinct letters are statistically different

The number of resin and amalgam fillings executed in premolars and molars at each Dental School is shown in Table 2. The number of patients treated at UFRGS and ULBRA was 207 and 178, respectively. Dental students from UFRGS placed more amalgam fillings than ULBRA students $(p=0.000)$. There was no statistic difference between the Dental Schools in the number of composite fillings executed $(p=0.086)$ (Table 2$)$.

Table 2: Number of Resin and Amalgam fillings executed in premolars (PM) and molars (M) at Dental Schools UFRGS and ULBRA/Canoas from July to December 2004.

\begin{tabular}{lcccccc} 
& Resin & \multicolumn{5}{c}{ Amalgam } \\
\cline { 2 - 7 } Dental \\
\cline { 2 - 7 } School & PM & M & Total & PM & M & Total \\
\hline UFRGS & 123 & 133 & $256^{\mathrm{a}}$ & 27 & 44 & $71^{\mathrm{b}}$ \\
& $(37.61 \%)$ & $(40.67 \%)$ & $(78.28 \%)$ & $(8.26 \%)$ & $(13.46 \%)$ & $(21.72 \%)$ \\
\hline ULBRA & 134 & 205 & $339^{\mathrm{a}}$ & 1 & 26 & $27^{\mathrm{c}}$ \\
& $(36.61 \%)$ & $(56.02 \%)$ & $(92.63 \%)$ & $(0.27 \%)$ & $(7.10 \%)$ & $(7.37 \%)$ \\
\hline
\end{tabular}

$\mathrm{P}=0.000$ (chi-square test); numbers followed by distinct letters are statistically different

Regarding the number of restored surfaces, more than half of the amalgam and resin fillings were placed in one surface cavities. Around $30 \%$ of the restorations comprised two surfaces cavities. Large restorations (3 - 5 surfaces) were placed in a smaller proportion at the Dental Schools using both amalgam and resin.

The response rate of the questionnaires was 100\%. From the questionnaires filled up by senior students, it was observed that they are graduating with skills and knowledge to perform posterior restorations with resins with good degree of confidence, regardless the University. On the other hand, the students referred to have low level of confidence to perform amalgam restorations.

At Dental Schools, most of the resin fillings of permanent posterior teeth were placed under rubber dam (UFRGS $=91.42 \%$ e ULBRA $=100 \%$ ). Some amalgam fillings were placed under a dry field with cotton rolls and salivary evacuation (22.86\% at UFRGS, $12.5 \%$ at ULBRA). The reason to choose the rubber dam in resin and amalgam restorations was mainly humidity control. For resin 
restorations, technique requirement appeared as the second reason for the use of rubber dam (Table 3). At the PHS, there is no access to rubber dam.

Table 3: Students reasons (\%) for choosing the rubber dam in Dental Schools according to the filling material amalgam (AM) or resin (R).

\begin{tabular}{|c|c|c|c|c|}
\hline \multirow[b]{2}{*}{ Reasons } & \multicolumn{2}{|c|}{ UFRGS } & \multicolumn{2}{|c|}{ ULBRA } \\
\hline & $\mathrm{AM} \%$ & $\mathrm{R} \%$ & $\mathrm{AM} \%$ & $\mathrm{R} \%$ \\
\hline $\begin{array}{l}\text { Technique } \\
\text { requirement }\end{array}$ & 5.71 & 40 & - & 20 \\
\hline Humidity control & 65.71 & 62.85 & 60 & 97.5 \\
\hline $\begin{array}{l}\text { Improve } \\
\text { restoration } \\
\text { quality }\end{array}$ & 2.85 & 5.71 & 7.5 & 7.5 \\
\hline $\begin{array}{l}\text { Make it easier } \\
\text { to work }\end{array}$ & 2.85 & 5.71 & 25 & 15 \\
\hline $\begin{array}{l}\text { Better viewing } \\
\text { and access }\end{array}$ & 17.14 & 14.28 & 37.5 & 7.5 \\
\hline Patient safety & 25.7 & - & 7.5 & 10 \\
\hline
\end{tabular}

Senior students were asked about the number of amalgam and resin fillings executed during the entire undergraduate course (Table 4). Most of them performed more than 15 composite fillings, while the number of amalgam fillings executed during dental course was variable. Almost $71.43 \%$ of the UFRGS dental students performed $4-9$ amalgam fillings while $77.5 \%$ of the ULBRA students performed 1-3 amalgam fillings. In this last Dental School, one undergraduate student (2.5\%) performed no amalgam filling during the entire Dentistry Course. The ratio of $16 / 19$ dentists in the PHS claimed execute amalgam fillings in posterior teeth.

Table 4: Estimative percentage of dental fillings (AM-Amalgam and RResin) placed by the students during all the under graduation period obtained by the questionnaire.

\begin{tabular}{lcccc}
$N^{\circ}$ & of & \multicolumn{2}{c}{ UFRGS } & \multicolumn{2}{c}{ ULBRA } \\
\cline { 2 - 3 } fillings & AM\% & R\% & AM\% & R\% \\
0 & 0 & 0 & 2.5 & 0 \\
$01 /$ mar & 8.57 & 0 & 77.5 & 0 \\
$04 /$ jun & 40 & 0 & 17.5 & 0 \\
$07 /$ set & 31.43 & 2.86 & 0 & 2.5 \\
$10 /$ dez & 11.43 & 0 & 0 & 0 \\
$13-15$ & 8.57 & 2.86 & 0 & 5 \\
$>15$ & 0 & 94.29 & 2.5 & 92.5
\end{tabular}

The reasons to choose amalgam or resin as a dental material for posterior teeth restoration are listed in Table 5. The main reasons for the choice of resin were esthetics and dental tissue preservation. Amalgam was chose due to its longevity, less sensitive technique and speed of execution.
Table 5: Reasons (\%) for choosing Amalgam (AM) or resin (R) at Dental Schools (UFRGS and ULBRA) and at Basic Health Units $(\mathrm{BHU})$.

\begin{tabular}{|c|c|c|c|c|c|c|}
\hline \multirow{3}{*}{ Reasons } & \multicolumn{2}{|c|}{ UFRGS } & \multicolumn{2}{|c|}{ ULBRA } & \multicolumn{2}{|c|}{$\mathrm{BHU}$} \\
\hline & $\mathrm{AM} \%$ & $\mathrm{R} \%$ & AM\% & $\mathrm{R} \%$ & AM\% & $\mathrm{R} \%$ \\
\hline & 68.57 & 0 & 22.5 & 15 & 31 & 5 \\
\hline $\begin{array}{l}\text { Less sensitive } \\
\text { technique }\end{array}$ & & & & & & \\
\hline Esthetics & 0 & 100 & 0 & 97.5 & 0 & 68 \\
\hline Longevity & 68.75 & 2.86 & 67.5 & 5 & 79 & 0 \\
\hline $\begin{array}{l}\text { Dental tissue } \\
\text { preservation }\end{array}$ & 0 & 85.71 & 0 & 95 & 5 & 63 \\
\hline Patient choice & 25.72 & 65.71 & 25 & 72 & 10 & 32 \\
\hline Ease of handling & 51.43 & 22.86 & 2.5 & 76 & 42 & 15 \\
\hline $\begin{array}{l}\text { Speed of } \\
\text { execution }\end{array}$ & 54.29 & 2.86 & 12.5 & 45 & 42 & 5 \\
\hline Biocompatibility & 5.71 & 14.29 & 0 & 40 & 16 & 21 \\
\hline
\end{tabular}

More than half of the dentists working in the sampled $\mathrm{BHU}$ were graduated at UFRGS (63\%). None of the dentists was graduated at ULBRA. Almost $80 \%$ of the dentists work at the BHU for more than 10 years.

\section{Discussion}

The results of the present study indicated the widespread use of resin restorations in posterior teeth in Dental Schools from the metropolitan region of Porto Alegre. However, amalgam is still the material of choice for dentists in the Public Health System of the same city.

According to a questionnaire obtained from Brazilians Dental Schools in 1999, from 5 to $55 \%$ of the Dental Schools curriculum time in operative dentistry was devoted to teach direct posterior resin restorations (GORDAN et al., 2000). In the present study, it was observed that $85.86 \%$ of the fillings placed in posterior teeth by dental students were done using tooth-colored material.

The American Dental Association has suggested that composite is indicated for moderated-sized class I and II as well as smaller cavities (ADA COUNCIL ON SCIENTIFIC AFFAIRS; ADA COUNCIL ON DENTAL BENEFIT PROGRAMS, 1998). In the present study, it was not found association between the number of restored surfaces and the material used in the restoration, amalgam or resin. The major proportion of fillings comprised one and two surfaces restorations; however, large fillings (3 - 5 surfaces) were also executed by the students.

Some studies reported the use of resin for large cavities $(\geq 3$ surfaces) in dental schools (LYNCH; MCCONNELL; WILSON, 2006), clinical trials (RASKIN et al., 1999), as well as in clinical practice (BURKE, 2004; GILMOUR; EVANS; ADDY, 2007). The teaching of resin for restoration of large cavities is controversial. In USA, $68 \%$ of the dental schools reported the use of resin for 3 surfaces in posterior teeth (LYNCH; MCCONNELL; WILSON, 2006). On the other hand, Japanese schools contra-indicated extensive composite restorations (FUKUSHIMA et al., 2000). In a recent study, whose aim was to investigate the teaching of posterior composites to undergraduate dental students in Japan, all evaluated schools taught the placement of composite in occlusal cavities in premolars and molars. However, 7 schools did not teach the placement of two-surface occlusoproximal composites in premolars and molars and 14 schools and 15 schools 
do not teach placement of three surface occlusoproximal composites in premolars and molars, respectively (HAYASHI et al., 2009). The same controversial situation is observed in clinical practice. UK Department of Health does not allow provision of resin in load bearing fillings, while in Australia dentists reported the use of composite for this purpose (BURKE, 2004). A long-term evaluation of extensive restorations in permanent teeth supported the view that amalgam restorations but not composite resin restorations can be used as an alternative to crowns due to its longevity (VAN NIEUWENHUYSEN et al., 2003)

Studies have shown the decreasing use of amalgam as a restorative material (BURKE, 2004; GILMOUR; EVANS; ADDY, 2007). At Nijmegen dental school (The Netherlands), amalgam is only trained in the pre-clinic and the complete stop of dental amalgam teaching is under debate (ROETERS; OPDAM; LOOMANS, 2004). In the year $2000,99.9 \%$ of the fillings were resin restorations leaving amalgam with $0.1 \%$ of all multi-surface restorations (ROETERS; OPDAM; LOOMANS, 2004). We can observe differences in the two Universities studied, UFRGS and ULBRA, in relation to the percentage of amalgam fillings in posterior teeth. The higher number of amalgam placed at UFRGS $(42,86 \%)$ in comparison to ULBRA $(12 \%)$ could be related to a curricular demand of at least four amalgam restoration per student in the Operative Dentistry Discipline at UFRGS. Although this study did not investigate the causes for the low use of amalgam in Dental Schools, one can find in the literature that some reasons are the improvements in resin and dentin bonding properties, patients and dentists preferences due to esthetic reasons and reduction in patients confidence in the safety of amalgam (ROETERS; OPDAM; LOOMANS; 2004; MCCOMB, 2005; GILMOUR; EVANS; ADDY, 2007). The reduced need for preparation and the strengthening effect on the remaining tooth were considered as the main reasons for the shift from dental amalgam to adhesive dentistry with resin composite at Nijmegen Dental School (ROETERS; OPDAM; LOOMANS, 2004). These new concepts that are applied to the teaching seem not to be directly transferred to the clinical practice.

The change from amalgam to resin in the dental material choice for posterior teeth at Dental Schools is not observed in the Public Health System. In agreement to the present results, amalgam is still the material of choice for restoration of posterior teeth by the clinicians (MITCHELL; KOIKE; OKABE, 2007; KOVARIK, 2009) and some dental schools (LOMBARD et al., 2009). A great number of dentists in UK (83\%) and Australia (75\%) agree that discontinuation of amalgam restricts dentist's ability to adequately treat patients (BURKE et al, 2003; RANDALL; VRIJHOEF; WILSON, 2003).

Another example of the disparity between the teaching and the clinical practice is the humidity control of the operatory field: in this survey, rubber dam was found to be mandatory in dental schools and not available in the PHS. In a survey with general dental practioners from UK, there was confusion amongst dentists regarding the need of rubber dam for posterior composite restorations (GILMOUR; EVANS; ADDY, 2007). Most of the Irish general dental practioners (77\%) and more than half of them (52\%) reported not to use rubber dam when placing amalgam and composite restorations in posterior teeth, respectively ( $\mathrm{LYNCH}$; MCCONNELL, 2007). It is also interesting that although rubber dam was routinely used by the final year dental students in Wales and Ireland, more than half of the respondents predicted that their use of rubber dam would decrease once in independent practice (MALA et al., 2009).

Information from general dentistry practice would assist schools in making improved curriculum decisions. When faced with curricular changes, dental schools should use data from the Public Health System and private clinics to determine the appropriate scope of students' competence and to match this knowledge with the skills needed in general dentistry practice. On the other hand, the majority of the scientific knowledge is developed in the academy. Therefore, improvement in dental practice can only be achieved by a real integration between academy, public health services and private clinicians.

\section{Conclusion}

The change from amalgam to resin in the dental material choice for posterior teeth at Dental Schools was not followed by the Public Health Dental System, where the amalgam is still widely used in posterior teeth.

\section{Acknowledgments}

The authors thank the dental students from UFRGS and ULBRA for their collaboration in the study. We also thank all Dentists from the Public Health System in Porto Alegre who helped us during the execution of the study. FAPERGS is thanked for the Research scholarship received by A. Macarevich.

\section{References}

ADA COUNCIL ON SCIENTIFIC AFFAIRS; ADA COUNCIL ON DENTAL BENEFIT PROGRAMS. Statement on posterior resin-based composites. J. Am. Dent. Assoc., Chicago, v. 129, no. 11, p.16271628, Nov. 1998.

BERNARDO, M. et al. Survival and reasons for failure of amalgam versus composite posterior restorations placed in a randomized clinical trial. J. Am. Dent. Assoc., Chicago, v. 138, no. 6, p. 775-783, June 2007.

BURKE, F.J. et al. Amalgam and composite use in UK general dental practice in 2001. Br. Dent. J., London, v. 194, no. 11, p. 613-618, June 2003. Discussion 09.

BURKE, F.J. Amalgam to tooth-coloured materials--implications for clinical practice and dental education: governmental restrictions and amalgam-usage survey results. J. Dent., Kidlington, v. 32, no. 5, p. 343-350, July 2004.

CHRISTENSEN G.J. Amalgam vs. composite resin: 1998. J. Am. Dent. Assoc., Chicago, v. 129, no. 12, p. 1757-1759, Dec. 1998.

DE MOOR, R.; DELME, K. [Black or white--which choice for the molars? Part 2. Which does one choose for the restoration of posterior teeth: amalgam or composite?]. Rev. Belge Med. Dent. (1984), Bruxellas, v. 63, no. 4, p. 135-146, 2008.

FUKUSHIMA, M. et al. Teaching of posterior composite restorations in Japanese dental schools. Int. Dent. J., London, v. 50, no. 6, p. 407411, Dec. 2000.

GILMOUR, A.S.; EVANS, P.; ADDY, L.D. Attitudes of general dental practitioners in the UK to the use of composite materials in posterior teeth. Br. Dent. J., London, v. 202, no. 12, p. E32, May 2007.

GORDAN, V.V. et al. Teaching of posterior resin-based composite restorations in Brazilian dental schools. Quintessence Int., Berlin, v. 31 , no. 10, p. 735-740, Nov./Dec. 2000. 
HAYASHI, M. et al. Teaching of posterior composites in dental schools in Japan. J. Oral Rehabil., Oxford, v. 36, no.4, p. 292-298, Apr. 2009.

KOVARIK, R.E. Restoration of posterior teeth in clinical practice: evidence base for choosing amalgam versus composite. Dent. Clin. North Am., Philadelphia, v. 53, no. 1, p. 71-76, Jan. 2009.

LOMBARD, R. et al. Teaching approaches in South African dental schools: direct restorative procedures. SADJ, Houghton, v. 64, no. 1, p. 18-20, Feb. 2009.

LYNCH, C.D.; MCCONNELL, R.J.; WILSON, N.H. Teaching the placement of posterior resin-based composite restorations in U.S. dental schools. J. Am. Dent. Assoc., Chicago, v. 137, no. 5, p. 619625, May 2006.

LYNCH, C.D.; MCCONNELL, R.J. Attitudes and use of rubber dam by Irish general dental practitioners. Int. Endod. J., Oxford, v. 40, no. 6, p. 427-432, June 2007.

MALA, S. et al. Attitudes of final year dental students to the use of rubber dam. Int. Endod. J., Oxford, v. 42, no. 7, p. 632-638, July 2009.

MCCOMB D. Class I and Class II silver amalgam and resin composite posterior restorations: teaching approaches in Canadian faculties of dentistry. J. Can. Dent. Assoc., Ottawa, v. 71, no. 6, p. 405-406, June 2005

MITCHELL, R.J.; KOIKE, M.; OKABE, T. Posterior amalgam restorations--usage, regulation, and longevity. Dent. Clin. North Am., Philadelphia, v. 51, no. 3, p. 573-589, July 2007.

MJOR, I.A.; WILSON, N.H. Teaching Class I and Class II direct composite restorations: results of a survey of dental schools. J. Am. Dent. Assoc., Chicago, v. 129, no. 10, p. 1415-1421, Oct. 1998.

PALANIAPPAN, S. et al. Three-year randomised clinical trial to evaluate the clinical performance, quantitative and qualitative wear patterns of hybrid composite restorations. Clin. Oral Investig., Berlin, v. 14, no. 4, p. 441-458, Aug. 2010.

RANDALL, R.C.; VRIJHOEF, M.M.; WILSON, N.H. Dentists' perceptions of trends in restorative dentistry in the UK. Prim. Dent. Care, London, v. 10, no. 2, p. 49-52, Apr. 2003.

RASKIN, A. et al. Clinical evaluation of a posterior composite 10-year report. J. Dent., Kidlington, v. 27, no. 1, p. 13-19, Jan. 1999.

ROETERS, F.J.; OPDAM, N.J.; LOOMANS, B.A. The amalgam-free dental school. J. Dent., Kidlington, v. 32, no. 5, p. 371-377, July 2004.

TOBI, H. Cost-effectiveness of composite resins and amalgam in the replacement of amalgam Class II restorations. Community Dent. Oral Epidemiol., Copenhagen, v. 27, no. 2, p. 137-143, Apr. 1999.

VAN NIEUWENHUYSEN, J.P. Long-term evaluation of extensive restorations in permanent teeth. J. Dent., Kidlington, v. 31, no. 6, p. 395-405, Aug. 2003.

WILSON, N.H. Curricular issues changing from amalgam to toothcoloured materials. J. Dent., Kidlington, v. 32, no. 5, p. 367-369, July 2004. 